\title{
Detection of Mycobacterium tuberculosis DNA in blood of patients with acute pulmonary tuberculosis by polymerase chain reaction and non-isotopic hybridisation assay
}

\author{
RAFFAELE DEL PRETE, ADRIANA MOSCA, MARINA D'ALAGNI, ROBERTO SABATO*, \\ VITO PICCA* and GIUSEPPE MIRAGLIOTTA \\ Institute of Medical Microbiology, University of Bari, Piazza G. Cesare, 4 1-70124 Bari and *Hospital for \\ Pulmonary Diseases, 'D. Cotugno', Viale O. Flacco, 65 1-70124 Bari, Italy
}

\begin{abstract}
The detection of Mycobacterium tuberculosis DNA in peripheral blood mononuclear cells (PBMC) by PCR and non-isotopic hybridisation assay was evaluated for the laboratory diagnosis of pulmonary $M$. tuberculosis infection. The PCR technique was based on the presence of IS6110, a DNA sequence specific for $M$. tuberculosis, and performed on PBMC from 30 patients belonging to the fifth group of the American Thoracic Society (ATS) classification of tuberculosis. The identification of amplification products was confirmed after electrophoresis by hybridisation with a non-isotopic probe in a DNA enzyme immunoassay (DEIA). Of the 30 blood samples studied by the PCR-DEIA technique, 26 gave positive results and four gave negative results. Blood samples from 30 subjects in a control group were negative by this technique. The data suggest that PCR-DEIA of blood may provide a sensitive, specific and useful means of diagnosing mycobacterial infection.
\end{abstract}

\section{Introduction}

Pulmonary tuberculosis represents an important health problem worldwide once more, because of the increasing number of AIDS patients [1] and the migration of infected individuals [2]. Despite recent advances in nucleic acid-based methodology, the definitive diagnosis of the disease still relies on both microscopy and culture. However, identification of acid-fast bacilli (AFB) in stained smears lacks sensitivity and cannot distinguish Mycobacterium tuberculosis from other mycobacteria. The Lowenstein-Jensen culture technique is a long process which requires up to 8 weeks to isolate the organism and further time is needed to identify the mycobacteria to species level. The new radiometric systems [3] and biphasic culture [4] require $>2$ weeks of specimen culture before a definite identification can be established. Rapid and sensitive tools for the diagnosis of tuberculosis have been developed recently. In this context, the amplification of specific nucleic acids by polymerase chain reaction (PCR) provides a means for both increasing the sensitivity of detection and reducing the time required to diagnose pulmonary tuberculosis $[5,6]$. Several

Received 2 July 1996; revised version accepted 30 Oct. 1996.

Corresponding author: Dr R. Del Prete. studies have reported the success of PCR for the detection of $M$. tuberculosis DNA in clinical specimens such as sputum [7-10]. In addition, some authors have recently suggested the possibility of detecting $M$. tuberculosis DNA in the blood of patients suffering from acute pulmonary tuberculosis [11-14]. The detection of $M$. tuberculosis DNA in peripheral blood mononuclear cells (PBMC) requires simpler specimen preparation than from sputa as blood is a relatively minor source of PCR-inhibiting substances. To determine the possibility of using blood to diagnose pulmonary tuberculosis, the present study compared a rapid and simple method of DNA extraction from PBMC from infected patients followed by a semiquantitative PCR-based assay and a new colorimetric micro-well plate hybridisation assay for amplicon detection with traditional microbiological investigations. Primers specific for the amplification of a 123-bp target located within IS6110, an insertion sequence that is repeated 10-12 times in the chromosomes of $M$. tuberculosis strains, were used $[15,16]$.

Materials and methods

\section{Reagents}

All reagents were purchased from Sigma unless otherwise specified. 


\section{Patients and clinical specimens}

Early morning sputum and citrated whole blood samples were collected simultaneously from 30 patients with active pulmonary tuberculosis (24 with primary infection and six with reactivation of tuberculosis). These patients were hospitalised at the Hospital for Pulmonary Diseases 'D. Cotugno', Bari, Italy, and had clinical symptoms, positive acid-fast smears of sputum (29 patients) or bronchoalveolar lavage (BAL) (from one patient with negative sputum examination), positive tuberculin skin tests (at least $10 \mathrm{~mm}$ diameter of induration) and chest radiography suggestive of pulmonary tuberculosis. After the isolation of M. tuberculosis from sputum (or BAL) by culture, the patients were classified as belonging to the fifth group according to the recommendations of the American Thoracic Society (ATS) [17].

At chest radiography none of the patients showed miliary tuberculosis, six exhibited a single pulmonary cavity, 17 had multiple pulmonary cavities, three had non-cavitary infiltrates and four had upper lobe infiltrates and hilary adenopathy. None of the patients had clinical or laboratory features of disseminated disease, but one patient had chronic renal insufficiency due to renal tuberculosis and another had tuberculous salpingitis. Ten patients were immunosuppressed: two patients were undergoing chemotherapy for breast cancer, one had a history of non-insulin-dependent diabetes mellitus and seven patients had chronic hepatitis (from alcohol abuse). None of the patients was receiving antituberculosis therapy at the time the clinical samples were obtained. Sputum and blood specimens from 30 healthy subjects with normal chest radiography, negative tuberculin skin tests and no history of pulmonary tuberculosis infection or exposure were used as controls.

\section{Microbiological investigations}

Microscopy and culture of respiratory tract specimens were performed by conventional methods [18]. About half of the sputum or BAL sample was subjected to direct microscopy by Ziehl-Neelsen staining. The remainder was digested and decontaminated by mixing with an equal volume of $\mathrm{NaOH} 2 \% \mathrm{w} / \mathrm{v}$, sodium citrate $1.45 \% \mathrm{w} / \mathrm{v}, \mathrm{N}$-acetyl-L-cysteine $0.5 \% \mathrm{w} / \mathrm{v}$ and incubating at room temperature for $20 \mathrm{~min}$. Sterile phosphate-

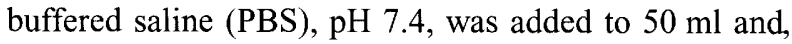
after vortex mixing for $15 \mathrm{~min}$, specimens were concentrated by centrifugation at $3000 \mathrm{~g}$ for $20 \mathrm{~min}$. The supernate was discarded and the sediment was resuspended in $2.0 \mathrm{ml}$ of PBS. For conventional culture, $0.5 \mathrm{ml}$ of this was inoculated on to Lowenstein-Jensen medium and incubated at $37^{\circ} \mathrm{C}$. Samples were examined for colonies daily for 1 week and then weekly for a total of 8 weeks.

\section{Identification of $M$. tuberculosis isolates}

Isolates growing on Lowenstein-Jensen medium were initially identified as potential mycobacteria on the basis of their colonial morphology and strong acid-fast staining and distinct rod morphology by Ziehl-Neelsen stain. Isolates were identified further by the niacin test [18]. To confirm the identification of the 30 isolates, DNA was extracted and subjected to PCR as described below. For DNA extraction, cells were harvested from Lowenstein-Jensen slants and suspended in $2 \mathrm{ml}$ of sterile TE buffer (10 mM Tris-HCl, pH 8.0, $1 \mathrm{~mm}$ EDTA). After centrifugation at $14000 \mathrm{~g}$ for $10 \mathrm{~min}$, the pellet was resuspended in a detergent solution (10 mM Tris- $\mathrm{HCl}$, pH 8.3, $1 \mathrm{~mm}$ EDTA, $50 \mathrm{~mm} \mathrm{KCl}$, $2.5 \mathrm{mM} \mathrm{MgCl}_{2}$, Tween $200.5 \%$, Nonidet P-40 0.5\%) and treated with proteinase $\mathrm{K}(200 \mu \mathrm{g} / \mathrm{ml})$ for $3 \mathrm{~h}$ at $56^{\circ} \mathrm{C}$. DNA was then extracted and purified with phenol:chloroform:isoamyl alcohol (25:24:1) followed by alcohol precipitation [19]. The pellet was resuspended in distilled water. The concentration and purity of DNA were determined by absorbance at 260 and $280 \mathrm{~nm}$ [19]. The extracted DNA was then subjected to the PCR-DEIA assay described below. The $M$. tuberculosis strain used as the source of DNA for the positive control was from our laboratory collection. It was cultured on Lowenstein-Jensen (Becton-Dickinson Microbiology Systems, Cockeysville, MD, USA) slants at $37^{\circ} \mathrm{C}$ and was subcultured every 2 months.

\section{Target preparation}

Blood specimens were processed promptly after collection to avoid lysis of red blood cells. The procedure for the preparation of target DNA from lymphocytes from peripheral whole blood was based on the protocol described by Kawasaki [20] with minor modifications. Briefly, PBMC from $2 \mathrm{ml}$ of citrated whole blood were isolated by density gradient centrifugation at $800 \mathrm{~g}$ for $15 \mathrm{~min}$ in a sterile tube (LeucoSep ${ }^{\mathrm{TM}}$, Opopharma AG, Zurich, Switzerland) with $3 \mathrm{ml}$ of gradient media (Lymphoprep ${ }^{\mathrm{TM}}$, Nyegaard and Co., Oslo, Norway) $(1.077 \mathrm{~g} / \mathrm{ml})$. PBMC were recovered and washed twice with $2 \mathrm{ml}$ of sterile TE buffer and centrifugation at $14000 \mathrm{~g}$ for $10 \mathrm{~min}$. The pellet was resuspended in $100 \mu \mathrm{l}$ of proteinase $\mathrm{K}$ solution $(200 \mu \mathrm{g} / \mathrm{ml}$ in $10 \mathrm{~mm}$ Tris- $\mathrm{HCl}, \mathrm{pH} 8.3,1 \mathrm{~mm}$ EDTA, $50 \mathrm{mM} \mathrm{KCl}, 2.5 \mathrm{mM} \mathrm{MgCl}_{2}$, Tween $200.5 \%$, Nonidet P-40 0.5\%) and incubated for $3 \mathrm{~h}$ at $56^{\circ} \mathrm{C}$. DNA was then extracted with an equal volume of a Chelex ${ }^{\mathrm{TM}}$-based DNA Extraction Reagent (PerkinElmer, Cetus, Norwalk, CT, USA) according to the manufacturer's instructions. A negative control consisting of TE buffer $(100 \mu \mathrm{l})$ was prepared as above with each batch of DNA extractions.

\section{Primers and PCR assay}

The PCR assay was performed with the primer pair P1 (5'-CCTGCGAGCGTAGGCGTCGG-3') and P2 
(5'-CTCGTCCAGCGCCGCTTCGG-3') synthesised by Sorin Biomedica, Saluggia, Italy, as described by Eisenach et al. [16]. The primers amplify a 123-bp sequence of the 'insertion element' IS6110, which is usually repeated several times in the chromosome of M. tuberculosis. Ten $\mu 1$ of the extract (or buffer) were subjected to PCR in a final volume of $100 \mu 1$ in $0.2-\mathrm{ml}$ microcentrifuge tubes containing $1 \times \mathrm{PCR}$ buffer $\left(10 \mathrm{~mm}\right.$ Tris- $\mathrm{HCl}, \mathrm{pH} 8.0,2.5 \mathrm{~mm} \mathrm{MgCl}_{2}, 50 \mathrm{~mm}$ $\mathrm{KCl}$, gelatin $0.01 \% \mathrm{w} / \mathrm{v}$ ), $0.2 \mathrm{mM}$ (each) of the four deoxyribonucleoside triphosphates (dATP, dUTP instead of dTTP, dGTP and dCTP), $2.5 \mathrm{U}$ of AmpliTaq ${ }^{\mathrm{TM}}$ DNA polymerase and $0.2 \mathrm{U}$ of uracil-N-glycosylase (UNG), all supplied in the GeneAmp PCR Reagent Kit (Perkin-Elmer Cetus) and $50 \mathrm{pm}$ each primer. Before amplification the PCR mixtures were incubated for $5 \mathrm{~min}$ at $50^{\circ} \mathrm{C}$. The PCR conditions for IS 6110 DNA amplification were an initial denaturation step of $94^{\circ} \mathrm{C}$ for $5 \mathrm{~min}$, followed by 35 cycles of $94^{\circ} \mathrm{C}$ for $2 \mathrm{~min}$, $68^{\circ} \mathrm{C}$ for $2 \mathrm{~min}$ and $72^{\circ} \mathrm{C}$ for $2 \mathrm{~min}$ and a final extension step at $72^{\circ} \mathrm{C}$ for $10 \mathrm{~min}$. The PCR procedure was accomplished with a thermocycler TC 9600 (Perkin-Elmer Cetus). Each experiment included two positive and two negative control tubes. The positive control tubes contained $0.5 \mathrm{pg}$ and $50 \mathrm{fg}$ of purified $M$. tuberculosis genomic DNA (corresponding to about 100 and 10 genome equivalents, respectively). Of the two negative control tubes, one contained the buffer subjected to the extraction procedure, and the other contained sterile water instead of target DNA. Each blood sample was processed by PCR assay in duplicate and in blinded fashion, i.e., without knowledge of the culture result. DNA extraction, PCR mixture preparation and post-PCR analysis were each carried out in separate rooms with dedicated equipment.

\section{Detection and identification of $P C R$ products}

Ten $\mu \mathrm{l}$ of amplified reactions were examined for products on an agarose $1.8 \% \mathrm{w} / \mathrm{v}$ gel in Tris-borateEDTA buffer (TBE) (45 mM Tris-borate, $\mathrm{pH} 8.3,1 \mathrm{~mm}$ EDTA) containing ethidium bromide $0.5 \mu \mathrm{g} / \mathrm{ml}$ by electrophoresis for $30 \mathrm{~min}$ at $40 \mathrm{~V}$ [19]. A DNA size marker (DNA mol.-wt marker V, Boehringer Mannheim, GmbH, Mannheim, Germany) was included on all gels for comparison. The products were visualised under UV transillumination at $302 \mathrm{~nm}$ (Pharmacia LKB, Biotechnology AB, Uppsala, Sweden).

Samples containing amplified products of the expected size (123 bp) were considered positive for the presence of $M$. tuberculosis DNA. The identification of the PCR products was verified by hybridisation with a biotinylated probe designed to hybridise with the amplified fragment under stringent conditions. The semi-quantitative ELISA-based detection system for PCR-amplified DNA (GEN-ETI-K, DNA enzyme immunoassay, DEIA, Sorin Biomedica, Saluggia, Italy) [21] was used with probe IS6110/31: 5'-GGCGAACCCTGCCCAGGTCGACACATAGGTG-3' (supplied with the DEIA kit) according to the manufacturer's instructions. The remaining amplification reaction volume $(90 \mu \mathrm{l})$ was submitted to the denaturation step (incubation for $15 \mathrm{~min}$ at $95^{\circ} \mathrm{C}$ ) and subsequent steps of the hybridisation technique. Following the manufacturer's recommendations, two positive controls (both containing the mycobacterial complemental sequence of IS6110:5' CACCTATGTGTCGACCTGGGCAGGGTTCGCC 3') and two negative controls, all supplied with the DEIA kit, were included, to validate the hybridisation procedure for every batch of the clinical samples. The optical density cut-off value between positive and negative samples was calculated as the mean absorbance of the two negative controls plus $0.10 \mathrm{~A}_{450}$ and this was used to score results as positive or negative.

\section{Sensitivity and specificity}

To assess the sensitivity of the combined PCR-DEIA assay, 10-fold serial dilutions in PBS of a homogenised suspension of $M$. tuberculosis cells from culture slants of the positive control (prepared as described by Kolk et al. [10]) were prepared and $1 \mathrm{ml}$ of each dilution was added to $1 \mathrm{ml}$ of citrated whole blood from healthy donors. Tubes containing $10^{2}-10^{8}$ organisms $/ \mathrm{ml}$ as determinated by the evaluation of $\mathrm{OD}$ at $420 \mathrm{~nm}$ [22], were subjected to DNA extraction and $10 \mu \mathrm{l}$ of the resulting solutions (containing $1-10^{6}$ organisms) were used for amplification and colorimetric detection.

\section{Results}

\section{Microbiology and PCR-DEIA of clinical specimens}

Among the samples from 30 patients with pulmonary tuberculosis, 29 sputa and one BAL fluid were positive by direct microscopy and culture (Table 1 ). In addition, AFB grown on Lowenstein-Jensen slants were confirmed as $M$. tuberculosis by both the niacin test and PCR technique (data not shown). PCR products of the expected size for $M$. tuberculosis were detected in 26 of 30 peripheral blood specimens from the patients diagnosed as having tuberculosis both microbiologically and clinically (Table 1 ). In one patient, while the

Table 1. Comparison of methods for the diagnosis of $M$. tuberculosis in clinical specimens

\begin{tabular}{lcccc}
\hline Clinical specimen & $\begin{array}{c}\text { Number of } \\
\text { samples } \\
\text { tested }\end{array}$ & microscopy & culture & PCR \\
\cline { 3 - 6 } & 30 & 30 & 30 & ND \\
\hline $\begin{array}{l}\text { Sputum* (infected } \\
\text { patients) }\end{array}$ & 30 & ND & ND & 26 \\
$\begin{array}{l}\text { Blood (infected } \\
\text { patients) }\end{array}$ & 30 & 0 & 0 & ND \\
$\begin{array}{l}\text { Sputum (controls) } \\
\text { Blood (controls) }\end{array}$ & 30 & ND & ND & 0 \\
\hline
\end{tabular}

ND, not determined.

*Includes one BAL specimen. 
examination of the sputum smear after Ziehl-Neelsen staining did not detect the presence of AFB, direct microscopy of the BAL showed the presence of a small number of AFB. Microbiological culture of the BAL fluid sample was positive after 8 weeks. PCR performed on a blood specimen obtained at the same time as sputum collection amplified a product of the expected size which was detected by agarose gel electrophoresis and confirmed by the hybridisation technique (Table 1). However, no amplification products were detected in blood from four patients with smear- and culture-positive sputum (Table 1); one of these samples was from an immunosuppressed patient with reactivation of tuberculosis and the other three were from immunocompetent patients with primary infection. To ascertain that the blood was not inhibitory for PCR, these samples were re-tested after the addition of $0.5 \mathrm{ng}$ of positive control M. tuberculosis DNA. The same procedure was followed for the samples from the 30 control subjects. No inhibition was detected. Microscopy, culture and PCR of blood samples from

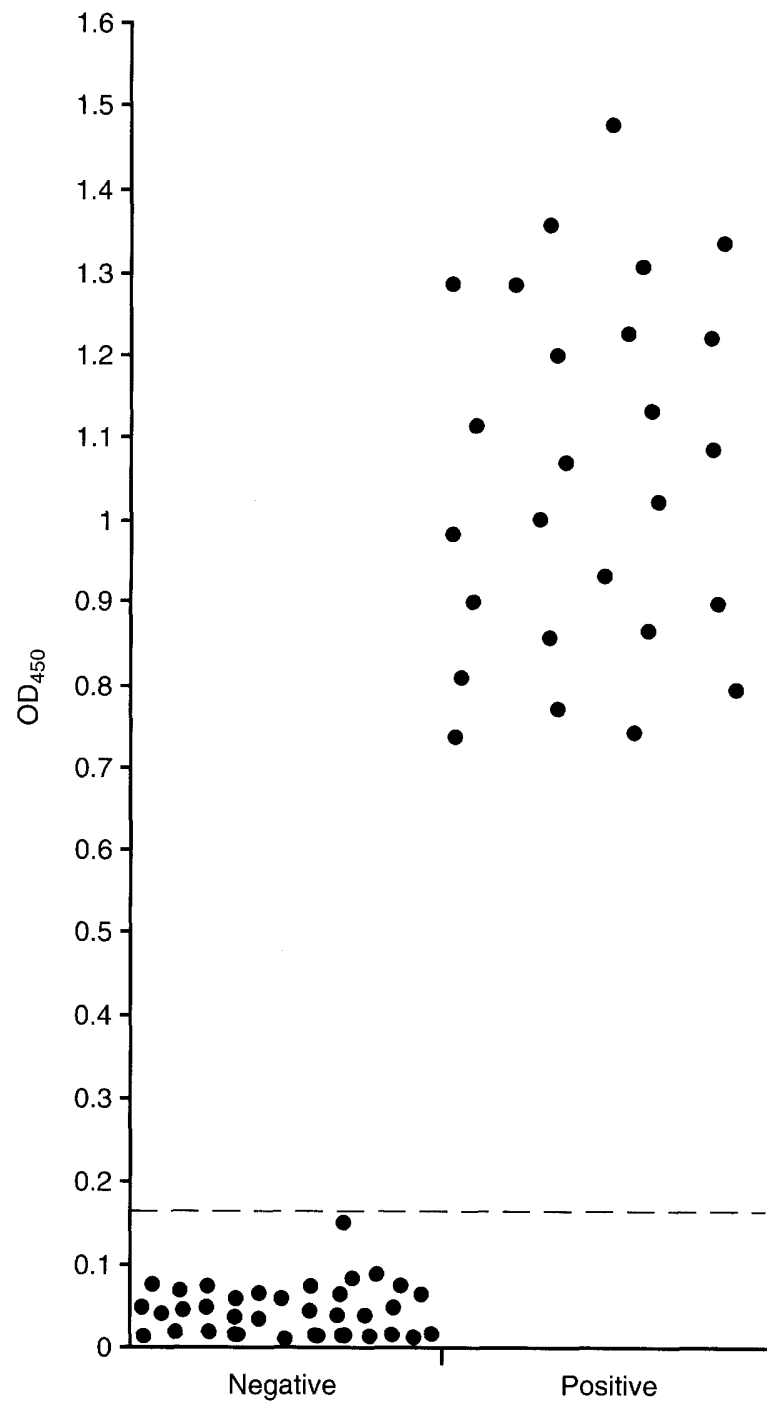

Fig. 1. Detection by DEIA of PCR-amplified products of $M$. tuberculosis DNA from blood samples. ---, cut-off for PCR-DEIA positivity; $\boldsymbol{\bullet}$, mean values of duplicate samples. the control group gave uniformly negative results (Table 1). The negative controls containing buffer or sterile water instead of DNA were also PCR negative and all of the M. tuberculosis positive controls were reactive.

After agarose gel electrophoresis the amplification reactions were analysed by hybridisation colorimetrically and the results confirmed the electrophoresis results (Fig. 1). In the colorimetric system the mean OD of the two DEIA negative controls was $0.050 \mathrm{~A}_{450}$ and the mean of the DEIA positive controls was 3.0 $\mathrm{A}_{450}$ (data not shown). Therefore, the OD cut-off value calculated in this study was $0.150 \mathrm{~A}_{450}$ and samples were classified as negative at $\mathrm{OD}_{450},<0.150$ or positive at $\mathrm{OD}_{450}, \geqslant 0.150$. The $26 \mathrm{PCR}$-positive specimens had ODs in the range $0.750-1.5 \mathrm{~A}_{450}$ (Fig. 1). The positive controls used in the PCR reaction (i.e., $0.5 \mathrm{pg}$ and $50 \mathrm{fg}$ of purified $M$. tuberculosis DNA) gave $\mathrm{OD}$ values $>2.0$ and $0.450 \mathrm{~A}_{450}$, respectively. Thirty blood specimens used as negative controls resulted in $\mathrm{OD}$ values in the range $0.035-0.065 \mathrm{~A}_{450}$ (Fig. 1). The OD values for the four samples from infected patients which gave negative results were $0.07,0.08,0.08$ and 0.14 .

\section{Sensitivity and specificity of the test}

To determine the specificity of the assay, the DEIAprobe had been tested previously with DNA from different Mycobacterium species. The probe hybridised exclusively with $M$. tuberculosis (data not shown). Agarose gel electrophoresis revealed a positive signal down to a limit of $c .10^{3}$ organisms. However, in the DEIA assay suspensions containing $>10$ mycobacteria gave OD values higher than the cut-off value. No products were detected by electrophoresis or DEIA of the negative controls.

\section{Discussion}

The results from the present study showed that PCR followed by hybridisation detected mycobacterial DNA circulating in the blood of $26(87 \%)$ of the 30 patients with pulmonary tuberculosis confirmed by traditional microscopy and culture of sputum or BAL (group 5 of the ATS recommendations) [17]. Therefore, these PCR findings are consistent with the results obtained by the traditional microbiological methods of mycobacterial diagnosis performed on sputa. However, microscopy has low sensitivity and culture may need to be continued for up to 8 weeks before the laboratory diagnosis can be made. PCR offers a promising new approach for rapid, safe and reproducible determination of $M$. tuberculosis infection [7]. Among biological materials, sputum is the obvious candidate in the context of pulmonary infections. Nevertheless, the preparation of target DNA from sputum samples is laborious and can produce PCR-inhibiting substances 
[9]. The demonstration of $M$. tuberculosis in the peripheral blood of animals, demonstrated after inoculation and culture [23], led us to investigate the suitability of patients' blood for detection of $M$. tuberculosis by PCR. Moreover, the possibility of mycobacteraemia has been suggested recently as activation of circulating human peripheral blood monocytes, which results in the expression of gene for IL-2R followed in turn by the appearence of IL-2R on the cells surface $[24,25]$ and the increase of IL-1 production, has been demonstrated during active human tuberculosis [26]. On the basis of these considerations this new technique was applied to the detection of $M$. tuberculosis in peripheral blood of patients with acute tuberculosis. As 10 of the 30 patients were suffering from immunosuppressive diseases, the data demonstrate that PCR assay of PBMC is useful for the diagnosis of tuberculosis in immunocompromised patients, as also pointed out by Kolk et al. [27], and in immunocompetent patients. The presence of mycobacteria in the blood of patients with pulmonary tuberculosis suggests that even if $M$. tuberculosis escapes from the alveolar space to the circulating blood more often than generally thought, this phenomenon is not necessarily correlated with disseminated infection. In one patient both microscopy and culture of the sputum were negative, whereas PCR on blood was positive. An explanation for this finding might be the difference in sensitivity between the methods per se, or when performed on different biological specimens. The negative results obtained when PCR was performed on PBMC from four patients with positive microscopy and culture of sputum might be due to incomplete bacterial lysis, as the presence of inhibitors was excluded by the successful amplification of blood samples after the addition of $M$. tuberculosis DNA. Alternatively, there may be $<10$ bacilli $/ \mathrm{ml}$ of blood, i.e. below the detection level of the PCR-DEIA technique, although the sensitivity of the colorimetric hybridisation technique is 5-10-fold greater than that of agarose gel electrophoresis. The wide range of ODs observed by the colorimetric hybridisation DEIA system for the positive samples (Fig. 1) may reflect variation in bacterial loads of the PBMC. Indeed, in the colorimetric system where PCR products are captured by a biotinylated probe attached to the microwell, the ODs are related to the initial amount of $M$. tuberculosis DNA [28]. Therefore, the method is semi-quantitative, assuming uniformity of heating throughout the thermocycler block, etc. However, the level of DNA in the PBMC sampled may not be related to the level of bacteraemia in patients.

The main obstacles for the successful performance of PCR-based techniques in a routine clinical laboratory are: (i) the difficulty of using radioisotopic detection techniques for PCR products; (ii) the presence of PCR inhibitors in clinical samples and (iii) 'carry-over' contamination and, consequently, the possibility of false-positive results. In the present study, the first problem was overcome with a non-radioactive detection system based on a $M$. tuberculosis specific biotinylated oligonucleotide probe (DEIA system). This probe is internal to the PCR product to be analysed, is immobilised on a streptavidin-coated microtitration plate and hybridises to denatured PCR products. Briefly, the DEIA test is a non-isotopic detection system based on the use of a mouse monoclonal antibody (27-14-D9, a hybridoma belonging to the IgG class) which binds specifically to double-stranded (ds) DNA. The addition of the anti-ds DNA antibody followed by horseradish peroxidase (HRP)-labelled anti-mouse IgG antibody, the hydrogen peroxide/tetramethylbenzidine substrate and the stop reagent ( $5 \%$ sulphuric acid) enables the detection of the hybridisation event as a strong yellow colour developing within $30 \mathrm{~min}$ of adding the substrate. The $\mathrm{OD}$ is then measured for each well by a spectrophotometer. This is a system of hybridisation analysis with high sensitivity and specificity and the technical advantage of low complexity. In our opinion, the detection of amplification products by agarose gel electrophoresis followed by hybridisation with the non-radioactive labelled probe, as described here, seems to be the most feasible amplicon detection method for the clinical microbiology laboratory. With regard to the second problem, the possibility of PCR inhibitors in blood (i.e., haem) was reduced by the use of the resin Chelex-100 as extraction reagent [29]. In addition, the isolation of PBMC with LeucoSep provides a less laborious and tedious process than other methods. LeucoSep is a commercially available disposable tube with two compartments separated by a porous barrier which allows PBMC to be obtained in a short time from undiluted blood by a single centrifugation step, with only slight contamination with red cells, granulocytes and platelets. Finally, prevention of 'carry-over' contamination was achieved by incubation of the PCR mixture for $5 \mathrm{~min}$ at $50^{\circ} \mathrm{C}$ to allow UNG enzyme to excise uracil from any contaminating dU-containing PCR products from previous amplification reactions [30].

Because of the ability of the micro-organisms to spread beyond the alveolar space to the bloodstream, the data indicate that PCR applied to blood may be a very sensitive method of determining the presence of mycobacteria or their fragments in the host. Although the absence of IS6110 has been demonstrated in rare M. tuberculosis strains [31], PCR amplification of this M. tuberculosis DNA target in blood represents a valuable additional diagnostic tool for the detection of infected individuals, in whom the organisms remain viable and are capable of causing disease for many years [32], enabling early diagnosis and reducing the costs of a patient's hospitalisation.

This study was supported in part by Ministero dell'Università e della Ricerca Scientifica (MURST) QUOTA 60\%, Italy, and was presented in part at the 7 th European Congress of Clinical Microbiology and Infectious Diseases, Vienna, March 26-30, 1995. 


\section{References}

1. Barnes PF, Bloch AB, Davidson PT, Snider DE. Tuberculosis in patients with human immunodeficiency virus infection. $N$ Engl $J$ Med 1991; 324: 1644-1650.

2. Anon. Tuberculosis among foreign-born persons entering the United States: Recommendations of the Advisory Committee for Elimination of Tuberculosis. MMWR Morbid Mortal Wkly Rep 1990; 39: 1-21.

3. Anargyros P, Astill DSJ, Lim ISL. Comparison of improved BACTEC and Lowenstein-Jensen media for culture of mycobacteria from clinical specimens. J Clin Microbiol 1990; 28: $1288-1291$

4. Isenberg HD, D'Amato RF, Heifets $\mathrm{L}$ et al. Collaborative feasibility study of a biphase system (Roche Septi-Check AFB) for rapid detection and isolation of mycobacteria. $J$ Clin Microbiol 1991; 29: 1719-1722.

5. Hance AJ, Grandchamp B, Levy-Frebault V et al. Detection and identification of mycobacteria by amplification of mycobacterial DNA. Mol Microbiol 1989; 3: 843-849.

6. Hermans PWM, Schuitema ARJ, Van Soolingen $\mathrm{D}$ et al. Specific detection of Mycobacterium tuberculosis complex strains by polymerase chain reaction. J Clin Microbiol 1990; 28: $1204-1213$

7. Brisson-Noel A, Gicquel B, Lecossier D, Levy-Frebault V, Nassif $\mathrm{X}$, Hance AJ. Rapid diagnosis of tuberculosis by amplification of mycobacterial DNA in clinical samples. Lancet 1989; 2: 1069-1071.

8. Buck GE, O'Hara LC, Summersgill JT. Rapid, simple method for treating clinical specimens containing Mycobacterium tuberculosis to remove DNA for polymerase chain reaction. $J$ Clin Microbiol 1992; 30: 1331-1334.

9. Del Portillo P, Murillo LA, Patarroyo ME. Amplification of species-specific DNA fragment of Mycobacterium tuberculosis and its possible use in diagnosis. J Clin Microbiol 1991; 29: 2163-2168.

10. Kolk AHJ, Shuitema ARJ, Kuijper $\mathrm{S}$ et al. Detection of Mycobacterium tuberculosis in clinical samples by using polymerase chain reaction and a nonradioactive detection system. J Clin Microbiol 1992; 30: 2567-2575.

11. Schluger NW, Condos R, Lewis S, Rom WN. Amplification of DNA of Mycobacterium tuberculosis from peripheral blood of patients with pulmonary tuberculosis. Lancet 1994; 344: 232-233.

12. Rolfs A, Beige J, Finckh U et al. Amplification of Mycobacterium tuberculosis from peripheral blood. J Clin Microbiol 1995; 33: 3312-3314.

13. Folgueira L, Delgado R, Palenque E, Aguado JM, Noriega AR. Rapid diagnosis of Mycobacterium tuberculosis bacteremia by PCR. J Clin Microbiol 1996; 34: 512-515.

14. Condos R, McClune A, Rom WN, Schluger NW. Peripheralblood-based PCR assay to identify patients with active pulmonary tuberculosis. Lancet 1996; 347: 1082-1085.

15. Thierry D, Brisson-Noël A, Vincent-Lévy-Frébault V, Nguyen $S$, Guesdon J-L, Gicquel B. Characterization of a Mycobacterium tuberculosis insertion sequence, IS6110, and its application in diagnosis. J Clin Microbiol 1990; 28: 2668-2673.

16. Eisenach KD, Cave MD, Bates JH, Crawford JT. Polymerase chain reaction amplification of a repetitive DNA sequence specific for Mycobacterium tuberculosis. J Infect Dis 1990; 161: $977-981$.

17. American Thoracic Society. Diagnostic standards and classification of tuberculosis. Am Rev Respir Dis 1990; 142: $725-735$.

18. Roberts GD, Koneman EW, Kim YK. Mycobacterium. In: Balows A, Hausler WJ, Hermann KL, Isenberg HD, Shadomy HJ (eds) Manual of clinical microbiology, 5th edn. Washington, DC, American Society for Microbiology. 1991: 304-339.

19. Sambrook J, Fritsch EF, Maniatis T. Molecular cloning: a laboratory manual, 2nd edn. Cold Spring Harbor, NY, Cold Spring Harbor Laboratory. 1989.

20. Kawasaki ES, Sample preparation from blood, cells, and othe fluids. In: Innis MA, Gelfand DH, Sninsky JJ, White TJ (eds) PCR protocols: a guide to methods and applications. San Diego, Academic Press. 1990: 146-152.

21. Mazza C, Mantero G, Primi D. DNA enzyme immunoassay: a rapid and convenient colorimetric method for diagnosis of cystic fibrosis. Mol Cell Probes 1991; 5: 459-466.

22. Schöningh R, Verstijnen CPHJ, Kuijper S, Kolk AHJ. Enzyme immunoassay for identification of heat-killed mycobacteria belonging to the Mycobacterium tuberculosis and Mycobacterium avium complexes and derived from early cultures. $J$ Clin Microbiol 1990; 28: 708-713.

23. Shapiro L. The frequency of bacillaemia in tuberculosis. $A m$ Rev Tuberc 1932; 26: 418-423.

24. Toossi Z, Sedor JR, Lapurga JP, Ondash RJ, Ellner JJ Expression of functional interleukin 2 receptors by peripheral blood monocytes from patients with active pulmonary tuberculosis. J Clin Invest 1990; 85: 1777-1784.

25. Ellner JJ, Spagnuolo PJ, Schachter BZ. Augmentation of selective monocyte functions in tuberculosis. $J$ Infect Dis 1981: 144: $391-398$.

26. Fujiwara $\mathrm{H}$, Kleinhenz ME, Wallis RS, Ellner JJ. Increased interleukin-1 production and monocyte suppressor cell activity associated with human tuberculosis. Am Rev Respir Dis 1986; 133: $73-77$

27. Kolk AHJ, Kox LFF, Kuijper S, Richter C. Detection of Mycobacterium tuberculosis in peripheral blood. Lancet 1994, 344: 694 .

28. Cho S-N, van der Vliet GME, Park $S$ et al. Colorimetric microwell plate hybridization assay for detection of amplified Mycobacterium tuberculosis DNA from sputum samples. J Clin Microbiol 1995; 33: 752-754.

29. Singer-Sam J, Tanguay RL, Riggs AD. Use of Chelex to improve the PCR signal from a small number of cells. Amplifications 1989; 3: 11.

30. Longo MC, Berninger MS, Hartley JL. Use of uracil DNA glycosylase to control carry-over contamination in polymerase chain reactions. Gene 1990; 93: 125-128.

31. Yuen LKW, Ross BC, Jackson KM, Dwyer B. Characterization of Mycobacterium tuberculosis strains from Vietnamese patients by southern blot hybridization. J Clin Microbiol 1993; 31: $1615-1618$.

32. Dannenberg AM. Immune mechanisms in the pathogenesis of pulmonary tuberculosis. Rev Infect Dis 1989; 11 Suppl 2: S369-S378. 